UDC 577.352.38: 594.14/.17

\title{
BIOCHEMICAL RESPONSES OF BIVALVE MOLLUSK UNIO TUMIDUS TO THE EFFECT OF NANOFORM OF ZINC OXIDE DEPENDING ON THE THERMAL REGIME
}

\author{
L. L. Gnatyshyna ${ }^{1,2}$, H. I. Falfushynska ${ }^{1,2}$, V. V. Mykhalska ${ }^{1}$, I. M. Maletska1, \\ V. V. Martyniuk', Z. Yu. Kubashok', A. V. Kharchuk', I. V. Soltys ${ }^{1}$, \\ N. Y. Mischuk', I. M. Sokolova ${ }^{3}$, O. B. Stoliar \\ ${ }^{1}$ Volodymyr Hnatyuk Ternopil National Pedagogical University \\ 2, Kryvonis St., Ternopil 46027, Ukraine \\ e-mail: Oksana.Stolyar@gmail.com \\ 2I.Ya. Horbachevsky Ternopil State Medical University, 1, Maydan Voli, Ternopil 46001, Ukraine \\ ${ }^{3}$ University of Rostock, 3, Albert-Einstein St., Rostock 18059, Germany
}

Indigenous bivalve mollusks from the cooling reservoirs of thermoelectric power plants (TPPs) are subjected to constantly elevated temperature and industrial pollution. Therefore, they could be regarded as a suitable model organisms adapted to the combination of typical novel environmental challengers in their habitats. The aim of this study was to elucidate the bioavailability of novel pollutant - nanoform of Zinc oxide $(\mathrm{nZnO})$ - in the mollusks from TPPs depending on the temperature of exposure. The metal accumulation and molecular responses of stress were investigated in the Unio tumidus (Unionidae) mollusks from two cooling reservoirs of TPPs (D- and B-groups) under the exposures to Zinc ions $(3.1 \mu \mathrm{M}), \mathrm{nZnO}(3.1 \mu \mathrm{M})$ at $18^{\circ} \mathrm{C}$, elevated temperature $\left(25^{\circ} \mathrm{C}\right)$, and $\mathrm{nZnO}$ at $25^{\circ} \mathrm{C}$ during 14 days. In most of the experimental groups, a selective increase of metal accumulation in metallothioneins in comparison with the tissue level, up-regulation of cytochrome $c$ level, and the decrease of oxyradical generation were detected in the digestive gland. In the gills, the increased DNA fragmentation was found. Under the $25^{\circ} \mathrm{C}$, the level of glutathione in the tissues was depleted. B-groups were distinguished by down-regulation of cholinesterase activity and increased level of cadmium in tissues. Thus, the biochemical responses of mussels from the cooling reservoirs reflect the lack of specific mechanisms of detoxification and prevalence of the nonspecific responses of stress. In the BPP-groups, the signs of toxicity indicate higher level of pollution in the reservoir.

Keywords: nano-ZnO, heating, bivalve mollusk, metallothioneins, stress.

\section{INTRODUCTION}

Contemporary environmental challenges are characterized by co-exposure to a sum of novel effects. Climate change and personal care products are of particular concern [1,12]. Their combination could cause unpredictable consequences of health 
status in aquatic habitants [10]. The cooling reservoirs of thermoelectric power plants (TPPs) are polluted by industrial effluents and have constantly elevated temperature regime ( $\sim$ by $5-7{ }^{\circ} \mathrm{C}$ in comparison with other water bodies in the area) [3]. Therefore the indigenous bivalve mollusks from the cooling reservoirs of TPPs could be regarded as a model organisms adapted to the novel environmental challengers [7]. Moreover, mussels are the main filtrators of surface water, including suspended particles. Therefore they are of particular interest for the study of the biological effect of engineering nanoparticles $[4,10]$. For the present study we selected the exposure to Zinc oxide nanoparticles $(\mathrm{nZnO})$ that are widely utilized in electronics and personal care products and expected to reach nowadays the concentrations as high as micrograms per liter in the surface waters [5]. Previously we compared the effects of $\mathrm{nZnO}$ under two thermal regimes and Zinc ions in the mussels from pristine area and detected highly distinct responses in each exposure [9]. Unlike the vertebrate animals [8], mussels were not able to utilize metal from $\mathrm{nZnO}$, whereas the responses to $\mathrm{Zn}$ and $\mathrm{nZnO}$ were distinct. Moreover, in this study the co-exposure to elevated temperature and $\mathrm{nZnO}$ abolished the effect of $\mathrm{nZnO}$ and caused the signs of toxicity. Therefore the present study aimed to elucidate whether the adaptation to thermal and chemical effects in the native habitat could modulate the response to $\mathrm{nZnO}$ and heating in the mussels. The selected for this study Dobrotvir and Burshtyn fuel TPPS belong to the most important energy producers. Burshtyn TPP is known as one of main polluters in Ukraine [http://en.necu.org.ua/ files/2013/07/Fact-sheet-for-PECI-Ukraine_final.pdf]. This study will provide the first knowledge on health status of the aquatic animals from the reservoirs of these TPPs.

\section{MATERIALS AND METHODS}

Adult Unio tumidus (Unionidae) ( 6 years old) were collected from the cooling ponds of Dobrotvir TPP (DPP, 50 $12^{\prime} \mathrm{N} 24^{\circ} 23^{\prime} \mathrm{E}$ ) and Burshtyn TPP (BPP, 49 $15^{\prime} \mathrm{N}, 2^{\circ} 35^{\prime} \mathrm{E}$ ) in West Ukraine in the September of 2015 y. Specimens were acclimated to the laboratory conditions for up to seven days in the aerated, dechlorinated, softened tap water. One group from the each TPP was utilized as control (C-groups). Other groups from both sites were exposed to Zinc ions $\left(\mathrm{ZnO}_{2}, 3.1 \mu \mathrm{M}\right)$, nanoform of Zinc oxide $(\mathrm{nZnO}, 3.1 \mu \mathrm{M})$ at $18{ }^{\circ} \mathrm{C}$, elevated temperature $\left(\mathrm{t}, 25^{\circ} \mathrm{C}\right)$, and $\mathrm{nZnO}$ at $25^{\circ} \mathrm{C}(\mathrm{nZnO}+\mathrm{t})$ during 14 days. For all biochemical traits except metallothionein (MT) concentration, digestive glands and gills were prepared individually from eight mollusks in each group. Tissue were sampled at $4{ }^{\circ} \mathrm{C}$ and frozen $\left(-40^{\circ} \mathrm{C}\right)$ until analyses. Tissue samples were homogenized $(1 / 10 \mathrm{w} / \mathrm{v})$ in $0.1 \mathrm{M}$ phosphate buffer, $\mathrm{pH} 7.4$, containing $100 \mathrm{mM} \mathrm{KCl}$ and $1 \mathrm{mM}$ EDTA, as well as $0.1 \mathrm{mM}$ phenylmethylsulfonyl fluoride to inhibit proteolysis. Protein concentration was measured by the method of Lowry et al. (1951). MTs were isolated as the thermostable proteins by size-exclusion chromatography on Sephadex G-50 as a pool from five individuals (totally from $350 \mathrm{mg}$ of tissue), and metals (Zinc ( $\mathrm{Zn}$ ), Copper (Cu), Cadmium $(\mathrm{Cd})$ ) in the corresponding eluate were detected after the digestion. Total metal concentrations in the tissue (Me) were also determined. The MTs concentration was calculated from metal $(\mathrm{Zn}+\mathrm{Cu}+\mathrm{Cd}$ ) concentrations (in $\mathrm{nmol} / \mathrm{g}$ ) in MT fraction. Total glutathione (GSH) concentration was quantified by the glutathione reductase recycling assay. The rates of oxyradical formation were determined using fluorescent dye dihydrorhodamine. DNA damage was evaluated by the levels of protein-free DNA strand (DNA sb) by the alkaline DNA precipitation assay using Hoescht 33342 dye. Cholinesterase (ChE, EC 3.1.1.7) activity was determined as the acetylthiocholine iodide-cleaving activity. The concentration of cytochrome $c$ was measured in the homogenate according to [11] and calculated

ISSN 1996-4536 (print) • ISSN 2311-0783 (on-line) • Біологічні Студії / Studia Biologica • 2017 • Том 11/№1 • С. 25-32 
from the difference in absorbance at $410 / 550 \mathrm{~nm}$ using a molar extinction coefficient of $10.6 \times 10^{4}$ and $2.77 \times 104 \mathrm{M}^{-1} \mathrm{~cm}^{-1}$ respectively.

Data were tested for normality and homogeneity of variance by using KolmogorovSmirnoff and Levene's tests, respectively. Whenever possible, data were normalized by Box-Cox common transforming method. For the data that were not normally distributed even after the transformation, non-parametric tests (Kruskall-Wallis ANOVA and MannWhitney U-test) were performed. Pearson's correlation test was used to assess correlations between the studied traits. The classification tree based on all studied trait was built using Classification and Regression Tree (CART) software using raw (non-transformed) data. All statistical calculations were performed with Statistica v. 10.0 and Excel for Windows-2010. Differences were considered significant if the probability of Type I error was less than 0.05 .

\section{RESULTS AND DISCUSSION}

The results of the study of metal distribution in the tissues with the participation of MTs (Fig. 1) had shown the increase of MTs level in the digestive gland of exposed mussels from both sites with one exception (t-BPP group). In the gills of the DPP-mussels the MT level was not changed by exposures. On the other hand, in the BPP-mussels Zn caused the prominent its elevation, whereas the exposures to $\mathrm{nZnO}$ and $\mathrm{nZnO}+\mathrm{t}$ led to its decrease (by $33.5 \%$ in $\mathrm{nZnO}+\mathrm{t}$-group). The rate of the MTs in the metal accumulation (Me-MT/Me) in the digestive gland was increased in all exposed groups (except of decrease in $\mathrm{nZnO}+\mathrm{t}$-group from BPP). This increase of the metal accumulation could reflect the adaptive response of MTs [2] that was not exposure-specific. In opposite, in the gills Me-MT/Me ratio had different exposure-dependent regularities in DPPand BPP-mussels. Importantly, the mussels from pristine site demonstrated the depletion of metalated MTs level in the same exposures [9]. However, the elevation of MT-Me in the present study was not specific for the exposures to $\mathrm{Zn}$ and $\mathrm{nZnO}$. Hence it reflected the non-specific adaptive response of MTs, whereas the bioavailability of $\mathrm{Zn}$ from $\mathrm{nZnO}$ was not evident. This adaptive response was better developed in the digestive gland of mussels from TPPs, particularly DPP, whereas in the mussels from pristine site and in the gills in BPP-groups it was attenuated.

The accumulation of $\mathrm{Cu}$ and $\mathrm{Cd}$ in the tissues of mussels was different depending on the tissue and origin of specimens. In the digestive gland of the DPP-mussels the avoiding of the accumulation of these metals was detected, whereas in the gills and, particularly, in the BPP-groups, over-accumulation of $\mathrm{Cu}$ (in the exposure to $\mathrm{Zn}$ ) was shown. Highly toxic Cd was hyper-accumulated in the both studied tissues of BPP-mussels in most exposures. It is important to mention that the differences between the populations of mussels in their ability to accumulate trace metals were evident even after the depuration for 21 days in the tap water. Nevertheless, the same regularities for the mussels from the sites with different level of pollution were also detected in other studies [7] and could be explained by the remarkable accumulative properties of these organisms [2, 4].

The characteristics of the stress and toxicity are represented on the Fig. 2 . The marker of metabolic activity cytochrome $c$ demonstrated the elevation in the digestive gland (DPP-group) under the exposures to $\mathrm{nZnO}$ and $\mathrm{nZnO}+\mathrm{t}$ (up to 1.9 times). In the gills the responses were not so regular. Oxyradical formation was decreased in the DPP-groups in the digestive gland by $\mathrm{Zn}$ and $\mathrm{nZnO}$ and was increased in the gills by $\mathrm{nZnO}$ in both DPP- and BPP-groups. Heating per se did not cause the oxidative shift. The level of glutathione in the BPP-mussels was highly sensitive to heating demonstrating decrease

ISSN 1996-4536 (print) • ISSN 2311-0783 (on-line) • Біологічні Студії / Studia Biologica • 2017 • Том 11/№1 • C. 25-32 

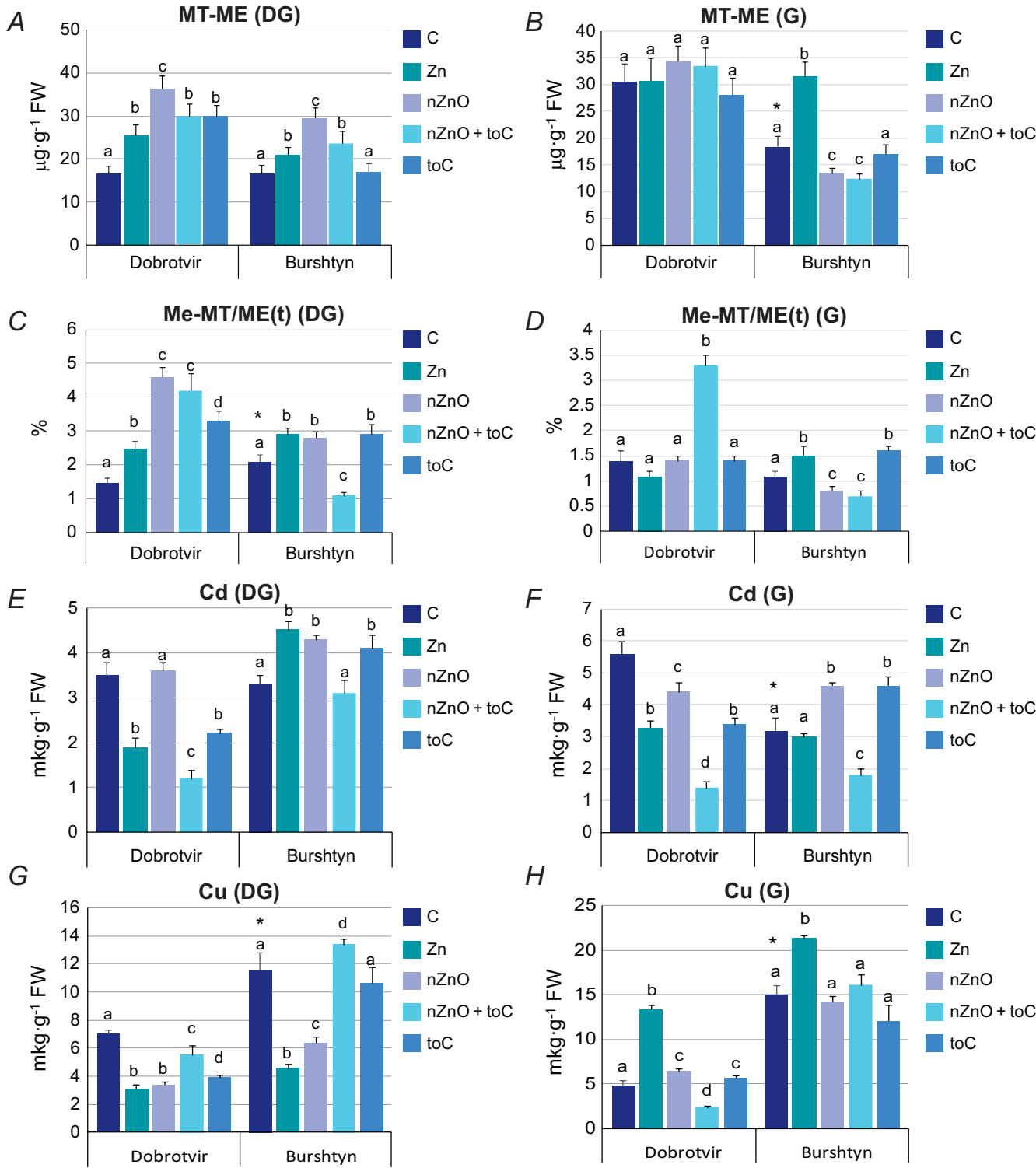

Fig. 1. The characteristics of metal accumulation in the tissues of digestive gland $(A, C, E, G)$ and gills $(B, D$, $F, H$ ) of U. tumidus from Dobrotvir and Burstyn cooling ponds (DPP and BPP) in at experimental exposures. Here and on Fig. 2, data are presented as means \pm SD, $n=8$ with the exception for MT-Me, where $n=3$ (from joint samples of 5 specimens). The corresponding columns that share the same letters indicate the values that are not significantly different $(P>0.05)$; ${ }^{*}$ - the significant difference between two control groups $(p<0.05)$

Рис. 1. Характеристики акумуляції металів у тканинах травної залози $(A, C, E, G)$ та зябер $(B, D, F, H)$ U. tumidus зі ставів-охолоджувачів Добротвора та Бурштина (DPP та BPP) за впливу експериментальних чинників. Тут і на рис. 2: результати представлені як $\mathrm{M} \pm \mathrm{m}, \mathrm{n}=8$ за винятком для MT-Ме, де $\mathrm{n}=3$ (об'єднаних зразків від 5 екземплярів). Відповідні колонки, що позначені однаковими буквами, відображають значення, які не відрізняються вірогідно $(P>0,05)$; ${ }^{*}$ відмінність між двома контрольними групами вірогідна, $p<0,05$ 
$A$

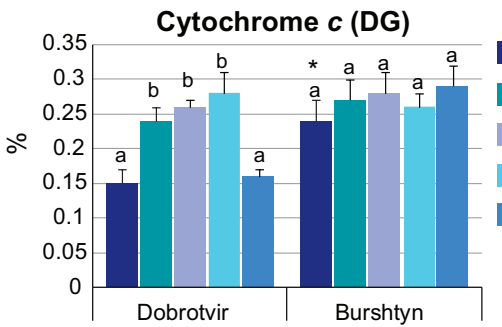

C

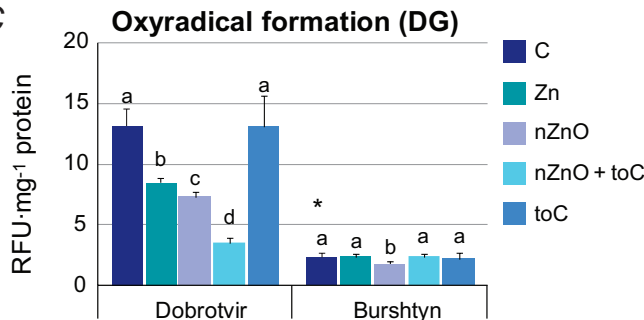

E

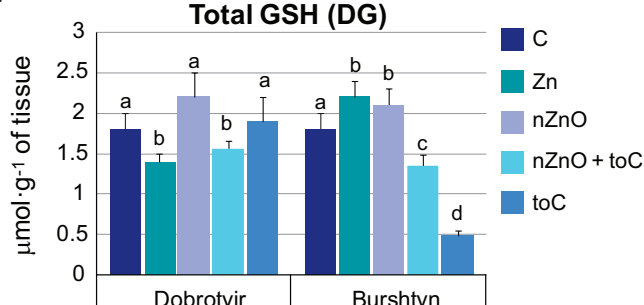

G

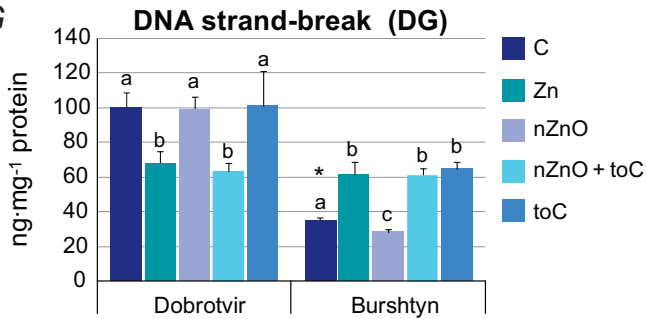

I

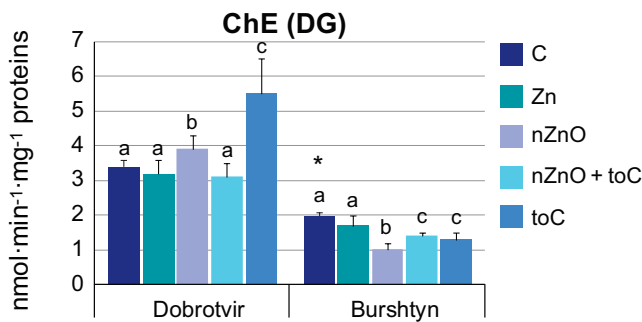

$B$

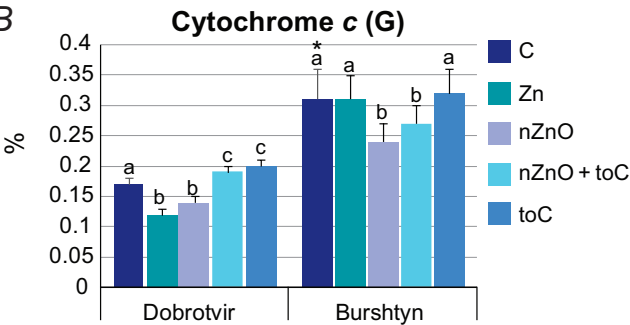

$D$

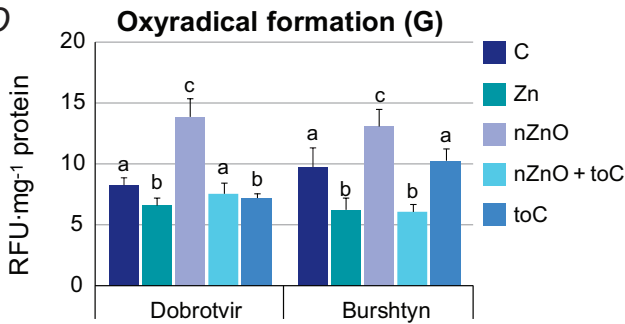

$F$
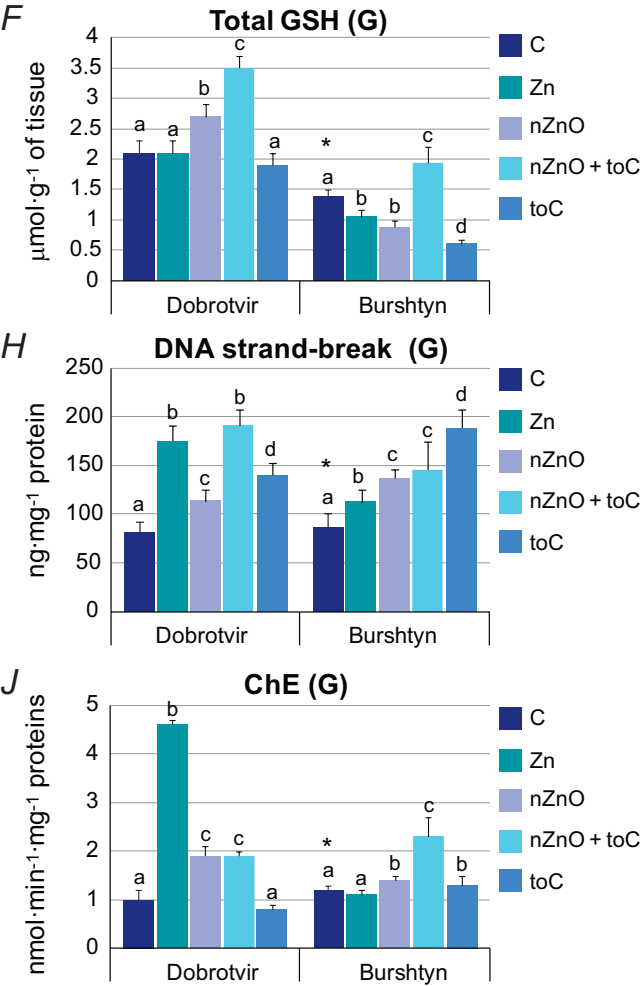

Fig. 2. Effects of experimental exposures on the indices of stress and toxicity in the digestive gland $(A, C, E$, $G, I)$ and gills $(B, D, F, H, J)$ of $U$. tumidus from Dobrotvir and Burstyn cooling ponds (DPP and BPP): $A, B$ - cytochrome $c$ concentration; $C, D$ - oxyradical formation; $E, F$ - total glutathione concentration; $G, H$ - DNA strand break; $I, J$ - Cholinesterase activity

Рис. 2. Вплив експериментальних експозицій на показники стресу і токсичності у травній залозі $(A, C$, $E, G, I)$ та зябер $(B, D, F, H, J) U$. tumidus зі ставів-охолоджувачів Добротвора та Бурштина (DPP і BPP): $A, B$ - концентарція цитохрому $C$; $C, D$ - утворення оксирадикалів; $E, F-$ загальна концентрація глутатіону; $G, H$ - фрагментація ДНК; $I, J$ - холінестеразна активність 
by 2-3 times, whereas in other exposures its changes were irregular, depending on the tissue and site. Thermal vulnerability of GSH of the mussels was also shown in our previous study [7].

The evaluation of the toxicity detected the prominent up-regulation of DNA fragmentation (by two times and more) in the gills of both DPP- and BPP-groups, whereas in the digestive gland this manifestation was detected only in the BPP-groups (except for $\mathrm{nZnO}$ BPP-group). The ChE depletion as a sign of neurotoxicity was detected only in the BPP-groups, mainly in the digestive gland, whereas in the DPP-groups its elevation was established in different exposures.

Pearson correlation analysis detected the positive correlations between MT-Me and MT-Me/Me levels in each tissue and the inter-correlation between the parameters of both tissues. The negative correlations for MT-Me and MT-Me/Me levels on the one hand and $\mathrm{Cu}$ and $\mathrm{Cd}$ concentrations on the other hand was shown in the both tissues $(p<0.05, \mathrm{n}=80)$ with one exception for Cd/MT-Me in the gills. Other established correlations were tissue-specific in most cases. According to CART analysis, the groups from DPP and BPP are clearly distinguished, mainly by the indices of digestive gland (with the exception of $\mathrm{nZnO}$ BPP-group in the gills) (Fig. 3).

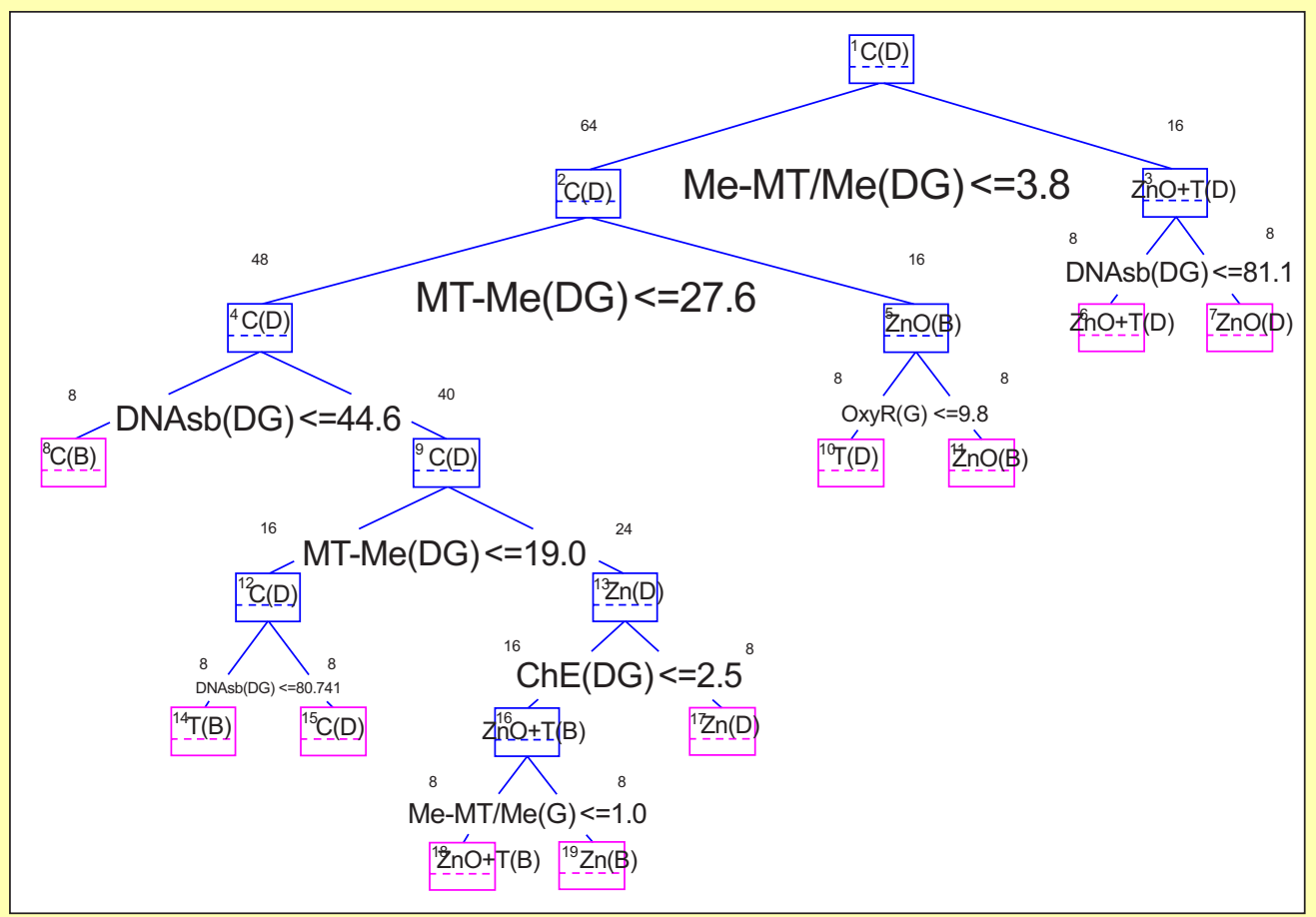

\section{Number of splits $=9 ;$ Number of terminal nodes $=10$}

Fig. 3. Results of classification tree analyses of the studied indices of $U$. tumidus from DPP (D) and BPP (B) in the experimental exposures. The number above each box indicates the number of animals in the respective group. Abbreviations: DG - digestive gland; G - gills

Рис. 3. Результати побудови класифікаційного дерева за дослідженими показниками U. tumidus з DPP (D) та BPP (B) у експериментальних експозиціях. Цифра над кожною коміркою позначає кількість тварин у відповідній групі. Скорочення: DG - травна залоза; G - зябра

ISSN 1996-4536 (print) • ISSN 2311-0783 (on-line) • Біологічні Студії / Studia Biologica • 2017 • Том 11/№1 • С. 25-32 
These regularities confirm the evidence of low bioavailability of $\mathrm{Zn}$ from $\mathrm{nZnO}$ in the mussels independently of their in situ exposure history [4, 9]. On the other hand, our results had shown that the characteristics of metal accumulation in the tissues represent the important indices for the distinguishing of health status of mussels from different habitats. In the same exposures the specimens from the pristine pond had shown distinct cellular responses to $\mathrm{Zn}$ and $\mathrm{nZnO}$ and inability to accumulate metals in MTs [9], whereas in the mussels from the cooling ponds different exposures caused similar sitedependent responses, especially the activation of MTs' metal binding function. This regularity could reflect the adaptation of mussels to the conditions of TPPs. Nevertheless, the molecular responses in the digestive gland in the DPP-mussels reflects better adaption to the exposures, whereas the indices of gills, particularly in BPP-groups detected the exhausting of adaptive response and signs of toxicity.

\section{CONCLUSIONS}

The increase of metal accumulation in MTs, up-regulation of cytochrome $c$ level and the decrease of oxyradical generation in the digestive gland were the most common responses in the mussels from two TPPs. The specific responses to $\mathrm{Zn}$ and $\mathrm{nZnO}$ were not evident. Down-regulation of cholinesterase activity and increased level of cadmium was detected in BPP-mussels. Thus, the biochemical responses of mussels from the cooling reservoirs reflect the lack of specific mechanisms of detoxification and prevalence of the nonspecific responses of stress. In the BPP-groups the signs of toxicity detect the higher level of pollution in the reservoir.

\section{ACKNOWLEDGMENTS}

This work has been supported by the Ministry of Education and Science of Ukraine (Project \# 131B, O.B.S.), U.S. Civilian Research and Development Foundation (CRDF) Cooperative Grants Program award (UKB1-7109-TE-13) to O.B.S. and I.M.S., Fulbright Scholarship and the West-Ukrainian Biomedical Research Centre grant awarded to H.I.F.

1. Abele D., Heise K., Pörtner H. O., Puntarulo S. Temperature-dependence of mitochondrial function and production of reactive oxygen species in the intertidal mud clam Mya arenaria. Journal of Experimental Biology, 2002; 205(3): 1831-1841.

2. Amiard J.C., Amiard-Triquet C., Barka S. et al. Metallothioneins in aquatic invertebrates: Their use as biomarkers. Aquatic Toxicology, 2006; 76(2): 160-202.

3. Baršiené J., Rybakovas A. Cytogenetic damage in gill and gonad cells of bivalve mollusks. Ekologija, 2008; 54(4): 245-250.

4. Canesi L., Ciacci C., Fabbri R. et al. Bivalve molluscs as a unique target group for nanoparticle toxicity. Marine Environmental Research, 2012; 76: 16-21.

5. Dumont E., Johnson A.C., Keller V.D., Williams R.J. Nano silver and nano zinc-oxide in surface waters - exposure estimation for Europe at high spatial and temporal resolution. Environmental Pollution, 2015; 196: 341-349.

6. Falfushynska H., Gnatyshyna L., Stoliar O. Effect of in situ exposure history on the molecular responses of bivalve mollusks to trace metals. Ecotoxicology and Environmental Safety, 2013; 89: 73-83.

7. Falfushynska H., Gnatyshyna L., Yurchak I. et al. Habitat pollution and thermal regime modify molecular stress responses to elevated temperature in freshwater mussels (Anodonta anatina: Unionidae). Science of the Total Environment, 2014; 500-501: 339-350.

8. Falfushynska H., Gnatyshyna L., Horyn O. et al. Endocrine and cellular stress effects of zinc oxide nanoparticles and nifedipine in marsh frogs Pelophylax ridibundus. Aquatic Toxicology, 2017; 185: 171-182. 
9. Falfushynska H., Gnatyshyna L., Yurchak I. et al. The effects of zinc nanooxide on cellular stress responses of the freshwater mussels Unio tumidus are modulated by elevated temperature and organic pollutants. Aquatic Toxicology, 2015; 162: 82-93.

10. Gagné F., Turcotte P., Auclair J., Gagnon C. The effects of zinc oxide nanoparticles on the metallome in freshwater mussels. Comparative Biochemistry and Physiology - Part C: Toxicology and Pharmacology, 2013; 158(1): 22-28.

11. Meeprom M., Sompong W., Suantawee T. et al. Isoferulic acid prevents methylglyoxal-induced protein glycation and DNA damage by free radical scavenging activity. BMC Complementary and Alternative Medicine, 2015; 15: 346.

12. Noyes P.D., Lema S.C. Forecasting the impacts of chemical pollution and climate change interactions on the health of wildlife. Current Zoology, 2015; 61(4): 669-689.

\title{
БIOХIMIЧНI РЕАКЦІЇ ДВОСТУЛКОВОГО МОЛЮСКА UNIO TUMIDUS HA ВПЛИВ НАНОФОРМИ ОКСИДУ ЦИНКУ ЗАЛЕЖНО ВІД ТЕПЛОВОГО РЕЖИМУ
}

\author{
Л. Л. Гнатишина ${ }^{1,2}$, Г. І. Фальфушинська ${ }^{1,2}$, В. В. Михальська ${ }^{1}$, І. М. Малецька1, \\ В. В. Мартинюк', 3. Ю. Кубашок', А. В. Харчук', І. В. Солтис', \\ Н. Й. Мішук', І. М. Соколова ${ }^{3}$ О. Б. Столяр ${ }^{1}$ \\ ${ }^{1}$ Тернопільський національний педагогічний університет імені Володимира Гнатюка \\ вул. М. Кривоноса, 2, Тернопіль 46027, Україна \\ e-mail: Oksana.Stolyar@gmail.com \\ ${ }^{2}$ Тернопільський державний медичний університет імені І.Я. Горбачевського \\ Майдан Волі, 1, Тернопіль 46001, Україна \\ ${ }^{3}$ Ростокський університет, вул. Альберта Ейнштейна, 3, Росток 18059, Німеччина
}

Двостулкові молюски з водойм-охолоджувачів теплових електростанцій (TEC) піддаються стабільно підвищеній температурі та промисловому забрудненню. Тому вони можуть бути зручними модельними організмами для дослідження комплексної дії сучасних загроз довкіллю завдяки адаптації до термального і хімічного впливу у природному середовищі існування. Метою роботи було з'ясувати біодоступність новітнього забруднювача - наноформи оксиду цинку (nZnO) - для молюсків з ТЕС залежно від температури експозиції. Досліджено акумуляцію металів та молекулярні реакції на стрес у молюсків Unio tumidus (Unionidae) із двох водойм-охолоджувачів ТЕС (Д- та В-групи) за впливу іонів цинку (3,12 мкM), nZnO (3,12 мкM) за $18^{\circ} \mathrm{C}$, підвищеної температури $\left(25^{\circ} \mathrm{C}\right)$ та $\mathrm{nZnO}$ за $25^{\circ} \mathrm{C}$ протягом 14 діб. У травній залозі молюсків у більшості експериментальних груп встановлено вибіркове збільшення акумуляції металів у складі металотіонеїнів порівняно із вмістом у тканині, зростання концентрації цитохрому с та зменшення генерації оксирадикалів. У зябрах відзначено підвищену фрагментацію ДНК. За температури $25^{\circ} \mathrm{C}$ зменшується вміст глутатіону в тканинах. В-групи вирізняються меншим діапазоном молекулярних детоксикаційних реакцій, пригніченням холінестеразної активності та збільшенням вмісту кадмію в тканинах. Відтак, біохімічні реакції молюсків з водойм TEC мають низьку залежність від природи експозиції, що відображає послаблення специфрічних реакцій детоксикації та перевагу неспецифрічних реакцій на стрес. У В-групах ознаки токсичності відображають вищий рівень забруднення водойми.

Ключові слова: нано-ZnO, тепловий ефрект, двостулковий молюск, металотіонеїн, стрес.

Одержано: 13.03.2017

ISSN 1996-4536 (print) • ISSN 2311-0783 (on-line) • Біологічні Студії / Studia Biologica • 2017 • Том 11/№1 • C. 25-32 